Check for updates

Cite this: RSC Adv., 2017, 7, 27128

\title{
Ferrite-based soft and hard magnetic structures by extrusion free-forming $\dagger$
}

\author{
Erwin Peng, (D) ${ }^{a}$ Xiangxia Wei, (DD ${ }^{a}$ Tun Seng Herng, ${ }^{a}$ Ulf Garbe, ${ }^{b}$ Dehong Yu ${ }^{b}$ \\ and Jun Ding*a
}

Functional ceramic materials, especially those with unique magnetic properties, with complex geometries have become increasingly important for various key technologies in industry. Herein, ferrite-based soft $\left(\mathrm{NiFe}_{2} \mathrm{O}_{4}\right)$ and hard $\left(\mathrm{BaFe}_{12} \mathrm{O}_{19}\right)$ bulk magnetic structures with three-dimensional morphologies are successfully fabricated from inexpensive metal oxide powder $\left(\mathrm{NiO} / \mathrm{Fe}_{2} \mathrm{O}_{3}\right.$ and $\left.\mathrm{BaCO}_{3} / \mathrm{Fe}_{2} \mathrm{O}_{3}\right)$ precursors through a simple extrusion free-forming (EFF) technique coupled with a high temperature solid-state reaction process. Dense polycrystalline microstructures with negligible porosity are observed for samples sintered above $1200{ }^{\circ} \mathrm{C}$ and highly crystalline $\mathrm{NiFe}_{2} \mathrm{O}_{4}$ and $\mathrm{BaFe}_{12} \mathrm{O}_{19}$ phases are successfully formed. The printed structures also exhibit either soft or hard magnetic material behavior with (i) saturation magnetization values up to approximately $86 \%$ and $95 \%$ of the $\mathrm{NiFe}_{2} \mathrm{O}_{4}$ and $\mathrm{BaFe}_{12} \mathrm{O}_{19}$ theoretical bulk magnetization values, respectively, and (ii) high densities up to $\sim 93 \%$ of their respective theoretical bulk density. Bulk magnetic structures with unique geometries (e.g. mesh, gear, ring and cylinder) are successfully fabricated. The EFF technique demonstrated in this work can be readily extended to other functional ferrite or titanate ceramic materials simply by changing the metal oxide powder precursors.

Received 20th March 2017

Accepted 4th May 2017

DOI: $10.1039 / \mathrm{c} 7 \mathrm{ra03251j}$

rsc.li/rsc-advances coercivity) with hexagonal structures (e.g. $\left.\mathrm{BaFe}_{12} \mathrm{O}_{19}\right)$ are of great interest among the various commercial classes of ferrites due to their excellent ferromagnetic behaviours (i.e. high magnetization). ${ }^{7,11}$

Often in applications, functional ceramic materials with complex geometries are required, especially ferrite ceramic materials for electromagnetic-related applications. ${ }^{\mathbf{1 3 - 1 5}}$ However, due to the limitations of the traditional ceramic processing techniques (e.g. casting and injection molding), the fabrication of such functional ceramic materials by classical routes is limited to simple shapes. In the literature, $\mathrm{NiFe}_{2} \mathrm{O}_{4}$ and $\mathrm{BaFe}_{12} \mathrm{O}_{19}$ materials have been reported to be processed into pellets or films using the die-pressing, slip-casting or tapecasting methods. ${ }^{16-20}$ To allow the fabrication of dense functional ceramic materials with complex geometries (e.g. mesh or patterned structures), many researchers have considered the possibilities of combining the traditional ceramic powder processing method with the additive manufacturing (AM) or rapid prototyping technologies. ${ }^{21-24}$ Numerous ceramic additive manufacturing processes have been extensively developed over the past decades. These include: (1) ceramic stereolithography, ${ }^{25,26}$ (2) ceramic selective laser sintering, ${ }^{27,28}$ (3) ceramic powder bed printing ${ }^{29,30}$ and (4) ceramic extrusion freeforming. . $^{\text {,31,32 }}$ The ceramic stereolithography (CSL) process involves the UV light curing of photopolymerizable ceramic suspensions, which is usually employed to fabricate various ceramics structures $\left(\right.$ e.g. $\left.\mathrm{Al}_{2} \mathrm{O}_{3}\right){ }^{26}$ Although functional ceramic materials (e.g. $\mathrm{BaTiO}_{3}$ and $\mathrm{PbZrTiO}_{3}$ ) have been successfully 
fabricated via the CSL technique, the fabrication of ferrite materials using the CSL technique it limited by severe light scattering due to the high refractive index of ferrite. ${ }^{33,34}$ On the other hand, ceramic selective laser sintering (SLS) and ceramic powder bed printing (binder jetting), which rely heavily on the coating of ceramic powders onto the printing bed and subsequent sintering or fusing processes, have also been reported for the fabrication of functional ceramic materials such as $\mathrm{BaFe}_{12} \mathrm{O}_{19}$ and $\mathrm{BaTiO}_{3} .{ }^{29,35,36}$ Despite the success in fabricating functional ceramic materials using the ceramic SLS and binder jetting techniques, the resultant structures reported are rather porous and therefore these techniques are not suitable for the fabrication of dense ferrite structures. Additionally, both the ceramic SLS and binder jetting techniques require expensive equipment.

Ceramic extrusion free-forming (EFF), commonly known as the robocasting process, allows the computer-controlled deposition of highly dispersed ceramic suspensions through a small orifice to form complex three-dimensional structures which is widely utilized to fabricate structural ceramic materials. ${ }^{21,31,32}$ Although the EFF printing resolution is highly dependent on the orifice size and the ceramic suspension processing, several functional ceramics materials such as titanates $\left(\mathrm{BaTiO}_{3}\right.$ and $\left.\mathrm{PbZrTiO}_{3}\right)$ and yttrium barium copper oxide $\left(\mathrm{YBa}_{2} \mathrm{Cu}_{3} \mathrm{O}_{7-x}\right)$ superconductors have been fabricated successfully. ${ }^{37-39}$ To date, the EFF technique remains as an interesting option for the fabrication of functional ceramic materials due to its economic advantage. Recently, Shah's group reported the fabrication of bulk ferrite materials via the EFF technique using toxic solventbased ceramic suspensions in dichloromethane; ${ }^{40}$ however, despite their success in fabricating various ferrite materials with unique hollow structures, the reported microstructures were highly porous. For various applications that demand good magnetic properties, highly dense ferrite structures are required. ${ }^{7}$ To the best of our knowledge, there is no existing report on the additive manufacturing of dense ferrite structures. Therefore, it is still a challenge to fabricate high density ferrite-based functional ceramic magnetic materials with desired three-dimensional shapes.

To address this challenge, herein, we report the successful fabrication of ferrite-based soft and hard bulk magnetic structures with three-dimensional morphologies from mixed metal oxide powder precursors through a simple EFF technique coupled with a high temperature solid-state reaction process. As described in Scheme 1, metal oxide starting precursors (NiO/ $\mathrm{Fe}_{2} \mathrm{O}_{3}$ or $\mathrm{BaCO}_{3} / \mathrm{Fe}_{2} \mathrm{O}_{3}$ ) were uniformly mixed prior to homogenization with organic additive solutions in deionized water containing polyvinyl alcohol (PVA) binder, polyethylene glycol (PEG) plasticizer and Solsperse dispersant simply using a mortar and pestle (in order to obtain better homogenization, a roller or planetary ball mill can be employed). Since water was used as the solvent instead of toxic/flammable organic solvents, the ceramic paste processing is harmless and inexpensive. ${ }^{40}$ The resultant mixed metal oxide containing suspensions (paste-like) were used as the feedstock for extrusion printing. The presence of thermoplastic binder and plasticizer ensured the proper rheology of the suspensions for the extrusion process by

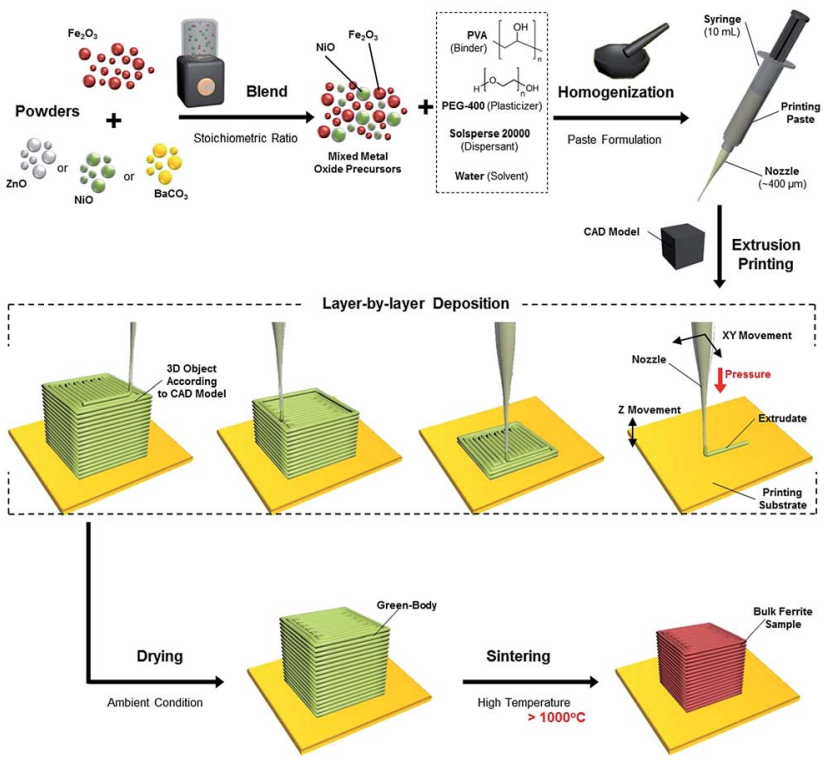

Scheme 1 Schematic diagram showing: extrusion ceramic paste preparation, extrusion free-forming (EFF) of bulk-ferrite green body and post-printing densification process to obtain bulk-ferrite structures.

endowing pseudo-plastic behaviours. The printed samples were then dried at ambient conditions before firing in a high temperature furnace for the sintering and densification process. Microstructure analysis, phase analysis and magnetic properties characterizations were performed on the 3D-printed bulk magnetic materials.

\section{Results and discussion}

\section{Precursor characterization and paste rheology}

In this work, analytical grade powder (bulk) of $\mathrm{NiO}, \mathrm{BaCO}_{3}$ and $\mathrm{Fe}_{2} \mathrm{O}_{3}$ were employed as starting precursors to form the bulk ferrite structure. Typically, these precursors are relatively cheap and commercially available. The microstructure analysis by SEM and TEM reveals the morphology of the $\mathrm{Fe}_{2} \mathrm{O}_{3}$ powder (Fig. $1 \mathrm{a}$ and $\mathrm{b}$ ) and the $\mathrm{BaCO}_{3} / \mathrm{Fe}_{2} \mathrm{O}_{3}$ and $\mathrm{NiO} / \mathrm{Fe}_{2} \mathrm{O}_{3}$ mixture (Fig. 1b-f). The $\mathrm{Fe}_{2} \mathrm{O}_{3}$ precursor particle size is less than $1 \mu \mathrm{m}$ and it has an irregular morphology. After mixing the $\mathrm{Fe}_{2} \mathrm{O}_{3}$ powder with $\mathrm{NiO}$ and $\mathrm{BaCO}_{3}$ powders using a cheap household blender, homogeneous powder mixtures were obtained.

Following the traditional ceramic processing route, the blended mixtures of $\mathrm{BaCO}_{3} / \mathrm{Fe}_{2} \mathrm{O}_{3}$ and $\mathrm{NiO} / \mathrm{Fe}_{2} \mathrm{O}_{3}$ powders were then homogenized with PVA binder, PEG-400 plasticizer and Solsperse dispersant to form the highly loaded ceramic suspensions. ${ }^{23}$ In unpublished results, the addition of excessive organic additives (especially binder and dispersant) caused the powder-filled ceramic suspensions to thicken significantly due to inevitable depletion flocculation. ${ }^{41}$ On the other hand, when insufficient binder and dispersant were added, the dispersion of the ceramic powders in the organic additives was not sufficient. Both scenarios resulted in severe paste clogging during the extrusion printing process. Based on numerous trial and 

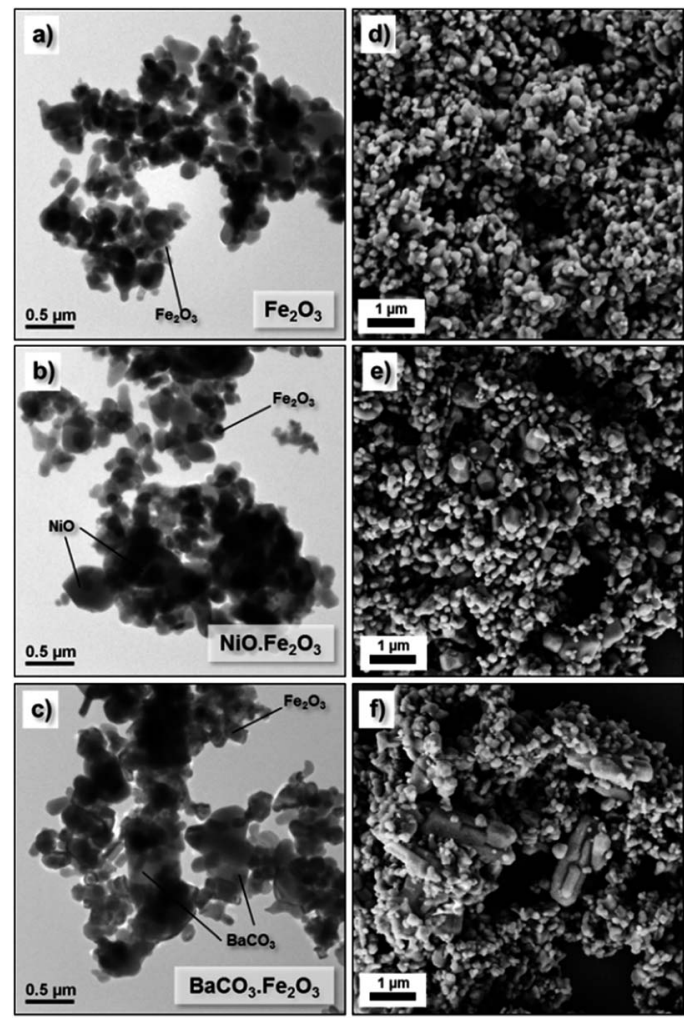

Fig. 1 SEM and TEM images of the powder precursors: $(a, d) \mathrm{Fe}_{2} \mathrm{O}_{3}$, (b, e) $\mathrm{NiO} / \mathrm{Fe}_{2} \mathrm{O}_{3}$ mixture and (c, f) $\mathrm{BaCO}_{3} / \mathrm{Fe}_{2} \mathrm{O}_{3}$ mixture

error experiments, the optimum (printable) paste formulations were obtained, which are summarized in Table 1 . The optimum contents of the charged polymeric binder and dispersant were found to be approximately $4-5 \mathrm{wt} \%$ and $0.5-1 \mathrm{wt} \%$, respectively, relative to the total powder precursor weight in order to promote successive deflocculation.

Rheological characterization of the powder-filled ceramic suspensions is very crucial in ensuring the extrudability of the paste through a small orifice ( 400 to $800 \mu \mathrm{m})$. For this, the apparent viscosity of the printable homogeneous $\mathrm{BaCO}_{3} \cdot \mathrm{Fe}_{2} \mathrm{O}_{3}$ and $\mathrm{NiO} \cdot \mathrm{Fe}_{2} \mathrm{O}_{3}$ ceramic precursor suspensions in between two parallel stainless steel plates with a gap of $800 \mu \mathrm{m}$ was measured at increasing shear rate $\left(0.01 \mathrm{~s}^{-1}\right.$ to $\left.40 \mathrm{~s}^{-1}\right)$, as shown in Fig. 2a. Independent from the ceramic starting precursors, the flow behaviours of both pastes demonstrate similar extensive shear-thinning behaviours in which their viscosity decreases as the shear rate increases. For both the $\mathrm{BaCO}_{3} \cdot \mathrm{Fe}_{2} \mathrm{O}_{3}$ and $\mathrm{NiO} \cdot \mathrm{Fe}_{2} \mathrm{O}_{3}$ containing ceramic pastes, the suspensions showed a similar steady state plateau in viscosity beyond a shear

Table 1 Compositions of the aqueous-based ceramic paste ${ }^{a}$

\begin{tabular}{llllll}
\hline Powder & Weight & PVA & PEG & Solsperse & Water \\
\hline $\mathrm{NiO} \cdot \mathrm{Fe}_{2} \mathrm{O}_{3}$ & $6.5 \mathrm{~g}$ & $280.0 \mathrm{mg}$ & $220.0 \mathrm{mg}$ & $70.0 \mathrm{mg}$ & $2.2 \mathrm{~mL}$ \\
$\mathrm{BaCO}_{3} \cdot \mathrm{Fe}_{2} \mathrm{O}_{3}$ & $6.0 \mathrm{~g}$ & $270.0 \mathrm{mg}$ & $220.0 \mathrm{mg}$ & $30.0 \mathrm{mg}$ & $2.3 \mathrm{~mL}$
\end{tabular}

${ }^{a}$ Optimized paste formulations.
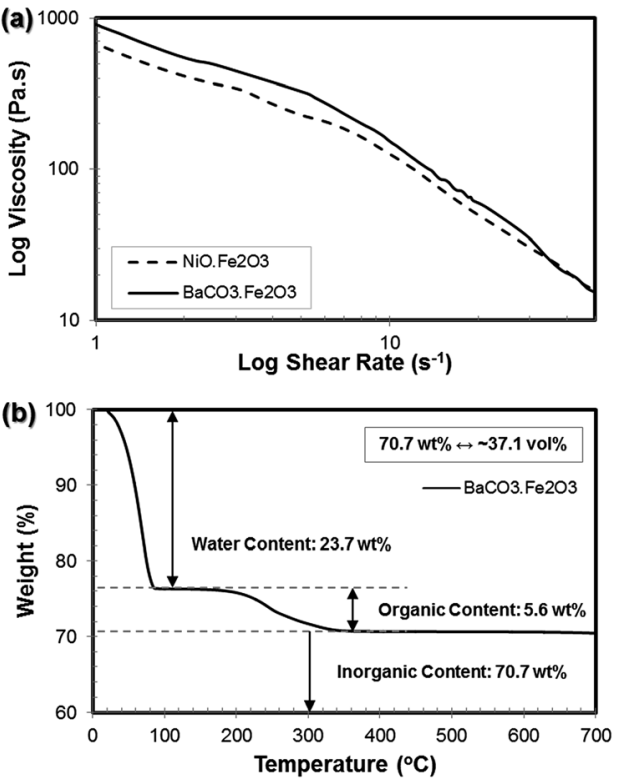

Fig. 2 (a) Flow ramps of the $\mathrm{BaCO}_{3} \cdot \mathrm{Fe}_{2} \mathrm{O}_{3}$ and $\mathrm{NiO} \cdot \mathrm{Fe}_{2} \mathrm{O}_{3}$ pastes showing viscosity as a function of shear rate (from $0 \mathrm{~s}^{-1}$ to $40 \mathrm{~s}^{-1}$ ). Shear thinning behaviors were observed for both metal oxide pastes. (b) Plot of the temperature-dependent weight loss of the $\mathrm{BaCO}_{3}$ . $\mathrm{Fe}_{2} \mathrm{O}_{3}$ paste (up to $700^{\circ} \mathrm{C}$ ) from the thermogravimetric analysis (TGA) experiment.

rate of $25 \mathrm{~s}^{-1}$. This pseudo-plastic behaviour of the ceramic paste is very important in the extrusion free-forming process. Inside the printing cartridge (10 $\mathrm{mL}$ plastic syringe), a high initial paste viscosity is important to avoid the particles from settling. When extruded at high shear rates induced by pressure, the shear-thinning behaviour facilitated the formation of complex ceramic structures. After the structure was formed and the pressure was removed, the paste thickened back to its original viscosity, thus allowing the retention of the extruded complex geometries. When the water evaporated, a dilatant mass was obtained which retained the original printing shape.

The shear rate during extrusion can be simply calculated by taking into account the volumetric paste flow rate through a small orifice (for more details on the calculations, please see ESI Section S1, Fig. S1†). ${ }^{32,42}$ Based on the printing parameters (nozzle diameter of $410 \mu \mathrm{m}$ and printing speed of $5 \mathrm{~mm} \mathrm{~s}^{-1}$ ), the shear rate in the nozzle during the extrusion process was estimated to be $\sim 31 \mathrm{~s}^{-1}$. Referring to the flow behaviours of the prepared paste (Fig. 2a), at this shear rate, the viscosities of the $\mathrm{BaCO}_{3} \cdot \mathrm{Fe}_{2} \mathrm{O}_{3}$ and $\mathrm{NiO} \cdot \mathrm{Fe}_{2} \mathrm{O}_{3}$ ceramic pastes were determined to be $16.54 \mathrm{~Pa}$ s and 28.95 Pa s, respectively, which are within the typical viscosity range of $10-100 \mathrm{~Pa} \mathrm{~s}$ required for a successful robocasting process. ${ }^{22}$

Based on the compositions of the as-prepared homogeneous paste formulations given in Table 1 , the inorganic powder contents were around $34.5 \mathrm{vol} \%$ for the $\mathrm{NiO} \cdot \mathrm{Fe}_{2} \mathrm{O}_{3}$ paste and $33.9 \mathrm{vol} \%$ for the $\mathrm{BaCO}_{3} \cdot \mathrm{Fe}_{2} \mathrm{O}_{3}$ paste. To quantitatively verify the compositions of the as-prepared pastes, thermogravimetric analysis (TGA) was conducted. The temperature-dependent weight loss of the pastes is indicated in Fig. 2b. At the 
beginning of the heating process, it was clearly observed that the solvent (water) evaporated completely at around $100{ }^{\circ} \mathrm{C}$. As the temperature further increased, the organic additive contents (binder, plasticizer and dispersant) were completely burned out above $350{ }^{\circ} \mathrm{C}$. The residual weight corresponds to the inorganic powder content of the homogeneous pastes (i.e. $\mathrm{BaCO}_{3}$ and $\mathrm{Fe}_{2} \mathrm{O}_{3}$ ). From this analysis, the water, organic additive and inorganic powder contents were determined to be approximately $23.7 \mathrm{wt} \%, 5.6 \mathrm{wt} \%$ and $70.7 \mathrm{wt} \%$, respectively. The 70.7 wt $\% \mathrm{BaCO}_{3} / \mathrm{Fe}_{2} \mathrm{O}_{3}$ powder content is equivalent to 37.1 vol\% of the powder content. In addition to the composition analysis, the TGA results also suggest that the intermediate debinding temperature of $500-600{ }^{\circ} \mathrm{C}$ in air atmosphere should be sufficient for a complete binder burnout.

\section{Soft magnet: nickel ferrite $\left(\mathrm{NiFe}_{2} \mathrm{O}_{4}\right)$}

The as-prepared homogeneous ceramic paste was shaped into 3D structures by extrusion through a nozzle using an inexpensive commercially available FDM printer (3Dison multi) equipped with a universal paste extruder (<USD 3500.00). The extruder feedstock was the ceramic paste, which was loaded in a disposable $10 \mathrm{~mL}$ plastic syringe and printing was driven by a rotating belt that pushed the plunger stepwise. In this case, a conical plastic nozzle with an approximately $410 \mu \mathrm{m}$ diameter was attached to the plastic syringe during the printing process. Several green bodies with a standard cubic shape (CAD dimension of $10 \mathrm{~mm}$ ) were conveniently fabricated using the $\mathrm{NiO} \cdot \mathrm{Fe}_{2} \mathrm{O}_{3}$ paste within a short period of time (less than an hour). Subsequently, these green bodies were sintered at various temperatures $\left(1000^{\circ} \mathrm{C}\right.$ to $1400{ }^{\circ} \mathrm{C}$ ) and durations (up to 60 hours) at $1{ }^{\circ} \mathrm{C} \mathrm{min}^{-1}$. Under the high temperature sintering conditions, a solid state reaction involving $\mathrm{NiO}$ and $\mathrm{Fe}_{2} \mathrm{O}_{3}$ (stoichiometric ratio) to form an $\mathrm{NiFe}_{2} \mathrm{O}_{4}$ phase was expected to occur together with sample densification. ${ }^{43}$ During the sample densification process, significant volume shrinkage was expected to occur when the relatively large pores (left behind by solvent evaporation and additives burnout) were eliminated from the structures. Digital photographs of some of these samples, including the original green body are presented in Fig. 3a. As expected, the sintered samples showed significant sample shrinkage (more than $20 \%$ ) compared to the original asprinted green body. Despite the shrinkage, the sintered body still retained the original shapes of the green body.

These sintered samples were examined under SEM to observe their microstructures. The low magnification SEM image of the printed cubes (Fig. S2 $\dagger$ ) display the layers of the deposited paste in the longitudinal direction that formed the three-dimensional model. From the high magnification SEM images of the sample surface given in Fig. $3 \mathrm{~b}-\mathrm{g}$, it is clearly observed that the grain size of the $\mathrm{NiFe}_{2} \mathrm{O}_{4}$ samples increased with an increase in the sintering temperature as well as an increase in sintering duration. In general, the samples sintered at $1300{ }^{\circ} \mathrm{C} / 60 \mathrm{~h}$ and above show a more densified structure than those sintered at lower temperatures $\left(1000{ }^{\circ} \mathrm{C} / 60 \mathrm{~h}\right.$ and $1200{ }^{\circ} \mathrm{C} /$ $60 \mathrm{~h}$ ). When the samples were sintered at a high temperature or for a longer duration, the porosity disappeared through
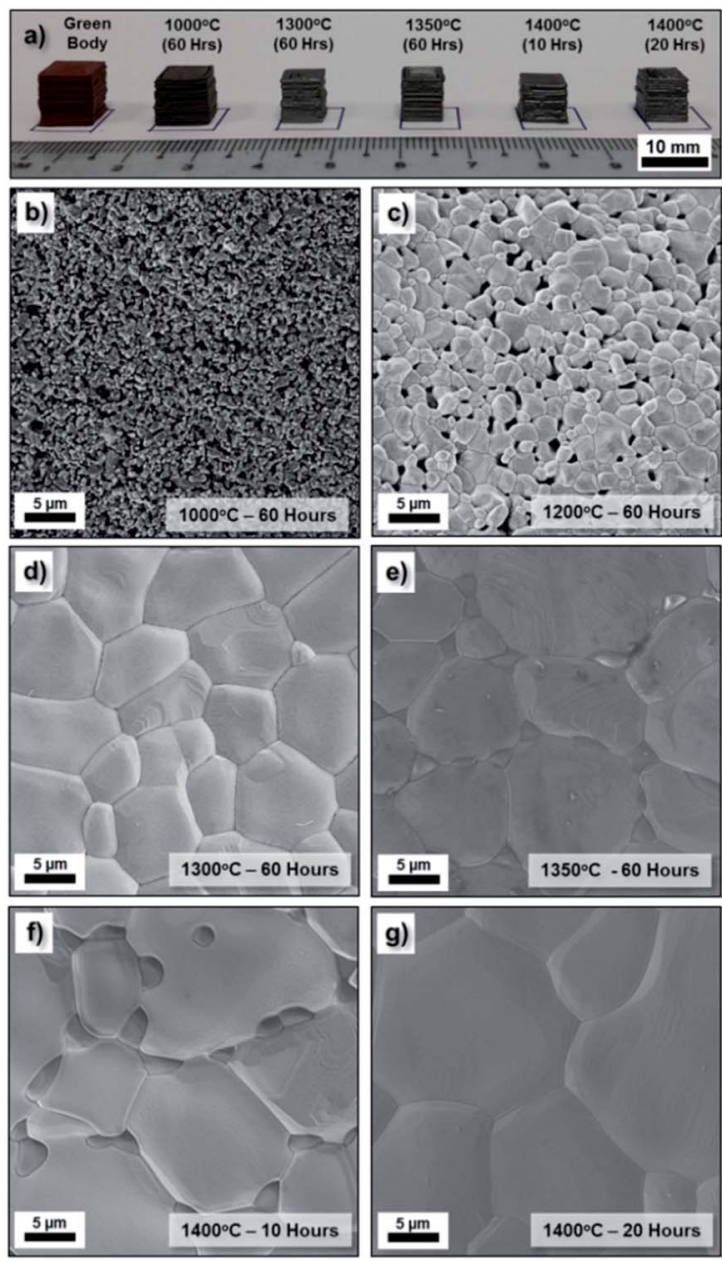

Fig. 3 (a) Digital photographs of the bulk as-printed 3D structures: $\mathrm{NiO} \cdot \mathrm{Fe}_{2} \mathrm{O}_{3}$ green body and $\mathrm{NiFe}_{2} \mathrm{O}_{4}$ structures sintered at $1000^{\circ} \mathrm{C} /$ $60 \mathrm{~h}, 1300{ }^{\circ} \mathrm{C} / 60 \mathrm{~h}, 1350{ }^{\circ} \mathrm{C} / 60 \mathrm{~h}, 1400{ }^{\circ} \mathrm{C} / 10 \mathrm{~h}$ and $1400{ }^{\circ} \mathrm{C} / 20 \mathrm{~h}$ (from left to right). SEM images of the $\mathrm{NiFe}_{2} \mathrm{O}_{4}$ structure sintered at (b) $1000^{\circ} \mathrm{C} / 60 \mathrm{~h}$, (c) $1200^{\circ} \mathrm{C} / 60 \mathrm{~h}$, (d) $1300^{\circ} \mathrm{C} / 60 \mathrm{~h}$, (e) $1350{ }^{\circ} \mathrm{C} / 60 \mathrm{~h}$, (f) $1400^{\circ} \mathrm{C} / 10 \mathrm{~h}$ and $(\mathrm{g}) 1400^{\circ} \mathrm{C} / 20 \mathrm{~h}$.

diffusion kinetics, grain growth occurred and the number of grain boundaries decreased significantly. The surface of the sintered $\mathrm{NiFe}_{2} \mathrm{O}_{4}$ structures appears to have a relatively smooth topology. Overall, the SEM images suggest well-sintered polycrystalline grain structures.

\section{Hard magnet: barium ferrite $\left(\mathrm{BaFe}_{12} \mathrm{O}_{19}\right)$}

Similarly to the $\mathrm{NiO} \cdot \mathrm{Fe}_{2} \mathrm{O}_{3}$ paste, the $\mathrm{BaCO}_{3} \cdot \mathrm{Fe}_{2} \mathrm{O}_{3}$ paste was also appropriately shaped into several standard cubic green bodies (CAD dimension of $10 \mathrm{~mm}$ ). These samples were then sintered at high temperatures $\left(1000{ }^{\circ} \mathrm{C}\right.$ to $\left.1400{ }^{\circ} \mathrm{C}\right)$. During sintering, especially during the slow ramping up process (at $1^{\circ} \mathrm{C}$ $\min ^{-1}$ ), barium carbonate decomposition resulted in barium oxide $(\mathrm{BaO})$ and carbon dioxide. The solid state reaction involving $\mathrm{BaO}$ and $\mathrm{Fe}_{2} \mathrm{O}_{3}$ (stoichiometric ratio) was expected to result in the $\mathrm{BaFe}_{12} \mathrm{O}_{19}$ single phase during the sample densification process. ${ }^{44}$ These sintered samples were examined under SEM to observe their microstructures. Similar to the $\mathrm{NiFe}_{2} \mathrm{O}_{4}$ 
samples, the low magnification SEM image of the printed cubes (Fig. S3†) reveals deposited layers in the longitudinal direction. From the high magnification SEM images of the sample surface given in Fig. $4 \mathrm{~b}-\mathrm{e}$, the grain size of the $\mathrm{BaFe}_{12} \mathrm{O}_{19}$ samples increased with an increase in sintering temperature. In general, the samples sintered at $1300{ }^{\circ} \mathrm{C} / 60 \mathrm{~h}$ and above showed a more densified structure than those sintered at lower temperatures $\left(1000^{\circ} \mathrm{C} / 60 \mathrm{~h}\right.$ and $\left.1200{ }^{\circ} \mathrm{C} / 60 \mathrm{~h}\right)$. It is also important to note that despite its dense microstructure, the $\mathrm{BaFe}_{12} \mathrm{O}_{19}$ sample exhibited significant grain growth which resulted in very long branched hexagonal structures when annealed at both $1300{ }^{\circ} \mathrm{C} /$ $60 \mathrm{~h}$ and $1400{ }^{\circ} \mathrm{C} / 10 \mathrm{~h}$.

The crystalline phases of the as-printed bulk ferrite structure were investigated using X-ray diffraction (XRD). The XRD patterns of the bulk $\mathrm{NiFe}_{2} \mathrm{O}_{4}$ and $\mathrm{BaFe}_{12} \mathrm{O}_{19}$ obtained at different sintering temperatures were shown in Fig. 5. The XRD patterns presented in Fig. 5 indicate highly crystalline structures without the presence of any impurity phases. All the peaks in Fig. $5 \mathrm{a}$ and $\mathrm{b}$ were indexed to the standard reflection pattern of the cubic spinel structure of $\mathrm{NiFe}_{2} \mathrm{O}_{4}$ (Trevorite; JCPDS \#742081) and $\mathrm{M}$-type hexagonal structure of $\mathrm{BaFe}_{12} \mathrm{O}_{19}$ (JCPDS \#391433). The presence of these characteristic peaks of the inverse spinel structure and hexagonal structure as well as the diminished initial characteristic peaks of the $\mathrm{NiO} \cdot \mathrm{Fe}_{2} \mathrm{O}_{3}$ and $\mathrm{BaCO}_{3}$ $\cdot \mathrm{Fe}_{2} \mathrm{O}_{3}$ powder precursors after high temperature $\left(\geq 1000{ }^{\circ} \mathrm{C}\right)$ sintering indicates the successful solid state reaction with
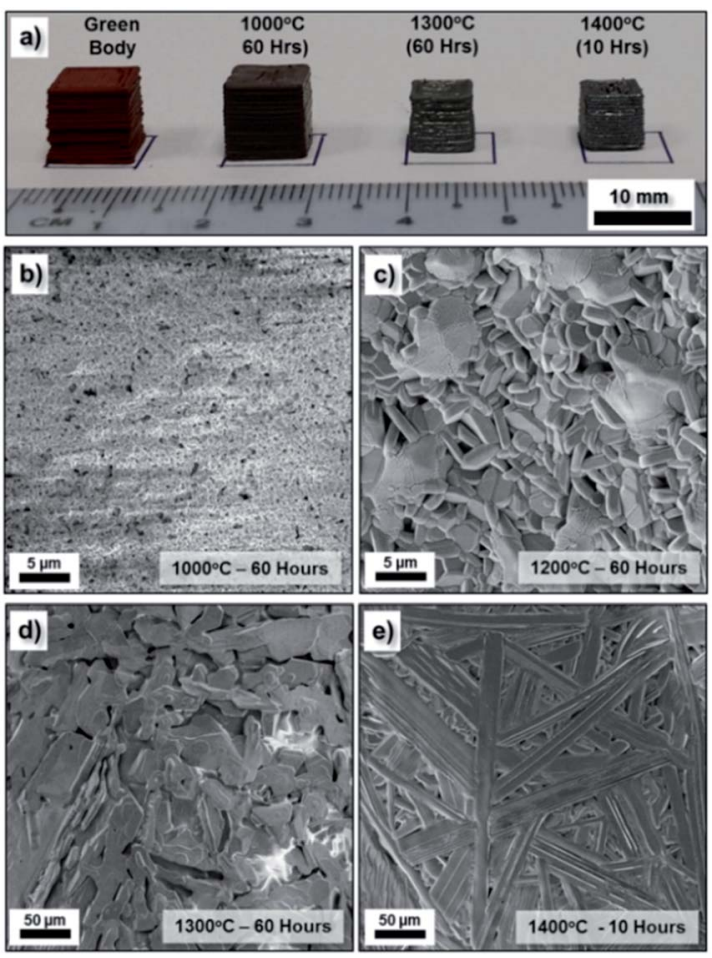

Fig. 4 (a) Digital photographs of the bulk as-printed 3D structure: $\mathrm{BaCO}_{3} \cdot \mathrm{Fe}_{2} \mathrm{O}_{3}$ green body and $\mathrm{BaFe}_{12} \mathrm{O}_{19}$ structures sintered at 1000 ${ }^{\circ} \mathrm{C} / 60 \mathrm{~h}, 1300{ }^{\circ} \mathrm{C} / 60 \mathrm{~h}$ and $1400{ }^{\circ} \mathrm{C} / 10 \mathrm{~h}$ (from left to right). SEM images of the $\mathrm{BaFe}_{12} \mathrm{O}_{19}$ structure sintered at (b) $1000{ }^{\circ} \mathrm{C} / 60 \mathrm{~h}$, (c) $1200^{\circ} \mathrm{C} / 60 \mathrm{~h}$, (d) $1300{ }^{\circ} \mathrm{C} / 60 \mathrm{~h}$ and (e) $1400{ }^{\circ} \mathrm{C} / 10 \mathrm{~h}$.
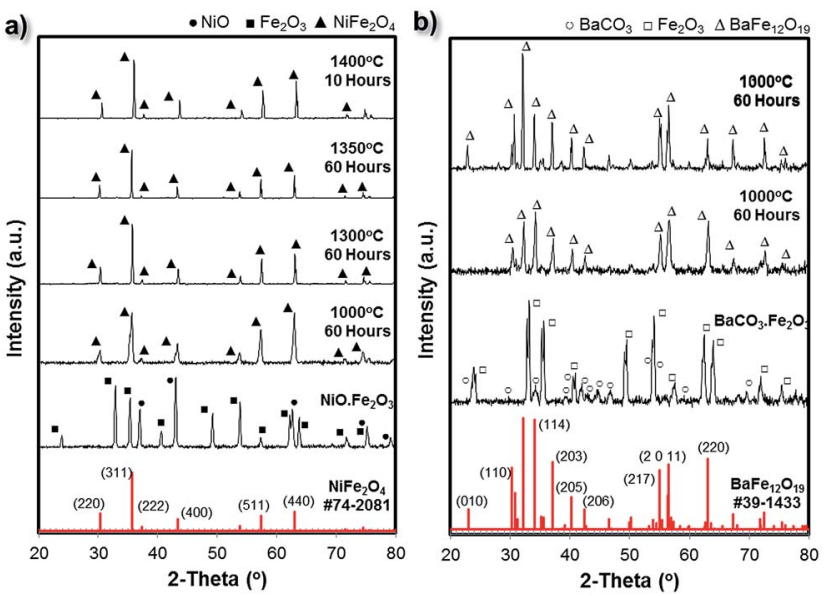

Fig. $5 \mathrm{X}$-ray diffraction spectra of the bulk ferrite 3D printed structures sintered under various conditions: (a) $\mathrm{NiFe}_{2} \mathrm{O}_{4}$ and (b) $\mathrm{BaFe}_{12} \mathrm{O}_{19}$. The XRD patterns of the $\mathrm{NiO} \cdot \mathrm{Fe}_{2} \mathrm{O}_{3}$ and $\mathrm{BaCO}_{3} \cdot \mathrm{Fe}_{2} \mathrm{O}_{3}$ mixtures as well as the standard XRD patterns of $\mathrm{NiFe}_{2} \mathrm{O}_{4}$ (\#74-2081) and $\mathrm{BaFe}_{12} \mathrm{O}_{19}$ (\#39-1433), which are highlighted in red, were included as references.

complete phase conversion (from the starting powder mixture to a single phase) during the high temperature densification process. No significant residual $\mathrm{Fe}_{2} \mathrm{O}_{3}$ phase was observed after the high temperature sintering, which highlights the possibility of obtaining high quality ferrite structures from precursors mixed by a blender. Therefore, we expect that the following classical solid-state reactions occurred during the sintering treatment: ${ }^{43,44}$

$$
\begin{gathered}
\mathrm{NiO}_{(\mathrm{s})}+\mathrm{Fe}_{2} \mathrm{O}_{3(\mathrm{~s})} \rightarrow \mathrm{NiFe}_{2} \mathrm{O}_{4(\mathrm{~s})} \\
\mathrm{BaCO}_{3(\mathrm{~s})}+6 \mathrm{Fe}_{2} \mathrm{O}_{3(\mathrm{~s})} \rightarrow \mathrm{BaO}_{(\mathrm{s})}+6 \mathrm{Fe}_{2} \mathrm{O}_{3(\mathrm{~s})}+\mathrm{CO}_{2(\mathrm{~g})} \uparrow \\
\mathrm{BaO}_{(\mathrm{s})}+6 \mathrm{Fe}_{2} \mathrm{O}_{3(\mathrm{~s})} \rightarrow \mathrm{BaFe}_{12} \mathrm{O}_{19(\mathrm{~s})}
\end{gathered}
$$

In addition to this, as the sintering temperature was increased from $1000{ }^{\circ} \mathrm{C}$ to $\geq 1300{ }^{\circ} \mathrm{C}$, the full-width at halfmaximum (FWHM) of the characteristic peaks of the cubic spinel structure of $\mathrm{NiFe}_{2} \mathrm{O}_{4}$ and hexagonal structure of $\mathrm{BaFe}_{12} \mathrm{O}_{19}$ decreased; whereas their relative intensities increased. This indicates the significant enhancement of the crystallite/grain size and the improvement in the crystallinity of the samples.

Fig. 6 summarizes the XPS analysis of the bulk 3D printed $\mathrm{NiFe}_{2} \mathrm{O}_{4}$ and $\mathrm{BaFe}_{12} \mathrm{O}_{19}$ samples. The survey spectrum (Fig. 6a) indicates the presence of four elements on the surface of the $3 \mathrm{D}$ printed structures: (samples i and ii) C 1s, O 1s, Fe 2p and Ba 3d for the $\mathrm{BaFe}_{12} \mathrm{O}_{19}$ samples and (samples iii and iv) C 1s, O 1s, Fe 2p and Ni 2p for the $\mathrm{NiFe}_{2} \mathrm{O}_{4}$ samples. In all 4 samples, the $\mathrm{C} 1 \mathrm{~s}$ peak $(284.6 \mathrm{eV})$ was used as a reference for the binding energy correction. No other impurity elements were detected in the samples within the detection limit.

The electronic state of the $\mathrm{Ba}$ and $\mathrm{Fe}$ elements for the $\mathrm{BaFe}_{12} \mathrm{O}_{19}$ samples or $\mathrm{Ni}$ and $\mathrm{Fe}$ elements for the $\mathrm{NiFe}_{2} \mathrm{O}_{4}$ samples were studied through XPS analysis. From Fig. 6b, the 

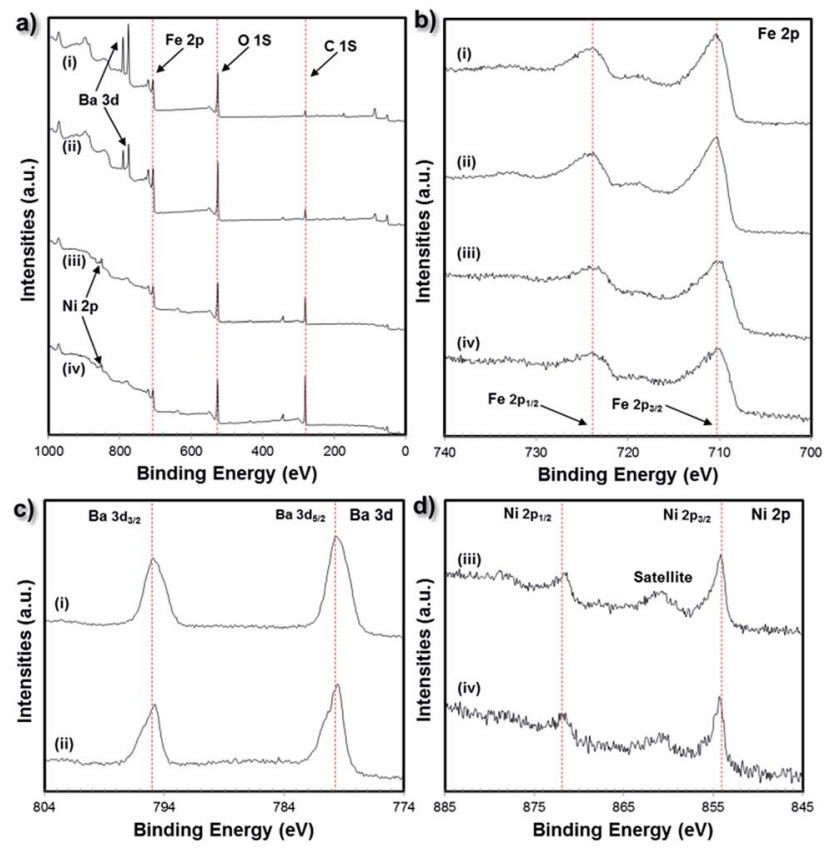

Fig. 6 (a) Wide survey scan XPS spectra and (b) Fe 2p XPS spectra of the 3D printed $\mathrm{NiFe}_{2} \mathrm{O}_{4}$ and $\mathrm{BaFe}_{12} \mathrm{O}_{19}$ samples. (c) $\mathrm{Ba} 3 \mathrm{~d}$ XPS spectra of the $\mathrm{BaFe}_{12} \mathrm{O}_{19}$ samples and (d) Ni 2p XPS spectra for the $\mathrm{NiFe}_{2} \mathrm{O}_{4}$ samples. Sample labels: (i) $\mathrm{BaFe}_{12} \mathrm{O}_{19}\left(1200{ }^{\circ} \mathrm{C} / 60\right.$ h), (ii) $\mathrm{BaFe}_{12} \mathrm{O}_{19}$ $\left(1300{ }^{\circ} \mathrm{C} / 60 \mathrm{~h}\right.$ ), (iii) $\mathrm{NiFe}_{2} \mathrm{O}_{4}\left(1350{ }^{\circ} \mathrm{C} / 60 \mathrm{~h}\right)$ and (iv) $\mathrm{NiFe}_{2} \mathrm{O}_{4}\left(1400{ }^{\circ} \mathrm{C} /\right.$ $20 \mathrm{~h})$

peaks for Fe $2 \mathrm{p}$ occurred at $710.4 \mathrm{eV}\left(\mathrm{Fe} 2 \mathrm{p}_{3 / 2}\right)$ and $724.5 \mathrm{eV}(\mathrm{Fe}$ $2 \mathrm{p}_{1 / 2}$ ) and a satellite peak at $718.6 \mathrm{eV}$ was present for both the $\mathrm{NiFe}_{2} \mathrm{O}_{4}$ and $\mathrm{BaFe}_{12} \mathrm{O}_{19}$ samples. The satellite peak at $8.2 \mathrm{eV}$ away from the main $\mathrm{Fe} 2 \mathrm{p}_{3 / 2}$ peak confirms the presence of the $\mathrm{Fe}^{3+}$ oxidation state. From Fig. $6 \mathrm{c}$, the two characteristic peaks at $795.2 \mathrm{eV}$ and $779.7 \mathrm{eV}$ correspond to $\mathrm{Ba} 3 \mathrm{~d}_{1 / 2}$ and $\mathrm{Ba} 3 \mathrm{~d}_{5 / 2}$, respectively, which indicate the presence of $\mathrm{Ba}^{2+}$ cations in the $\mathrm{BaFe}_{12} \mathrm{O}_{19}$ samples. From Fig. 6d, the peaks at the binding energies of $854.3 \mathrm{eV}$ and $871.7 \mathrm{eV}$ corresponded to Ni $2 \mathrm{p}_{3 / 2}$ and Ni $2 \mathrm{p}_{1 / 2}$, respectively. A shake-up satellite peak at $860.8 \mathrm{eV}$ was observed at the high binding energy side of the Ni $2 \mathrm{p}_{3 / 2}$ spectrum. The main peaks and the presence of this satellite peak indicate the presence of $\mathrm{Ni}^{2+}$ cations in the $\mathrm{NiFe}_{2} \mathrm{O}_{4}$ structures. Since the XPS analysis of both the bulk 3D printed $\mathrm{NiFe}_{2} \mathrm{O}_{4}$ and $\mathrm{BaFe}_{12} \mathrm{O}_{19}$ samples did not reveal traces of any other oxidation states, this suggests the complete conversion of the $\mathrm{NiO} / \mathrm{Fe}_{2} \mathrm{O}_{3}$ powder mixture to the $\mathrm{NiFe}_{2} \mathrm{O}_{4}$ single phase and $\mathrm{BaCO}_{3} \cdot \mathrm{Fe}_{2} \mathrm{O}_{3}$ powder mixture to the $\mathrm{BaFe}_{12} \mathrm{O}_{19}$ single phase according to eqn (1) and (2), respectively, during the high temperature sintering and densification process.

\section{Magnetic properties of the bulk $\mathrm{NiFe}_{2} \mathrm{O}_{4}$ and $\mathrm{BaFe}_{12} \mathrm{O}_{19}$ structures}

The room temperature magnetic properties of the 3D printed bulk ferrite structures were studied using a vibrating sample magnetometer (VSM). Fig. 7 shows the magnetic hysteresis loops of both the $\mathrm{NiFe}_{2} \mathrm{O}_{4}$ and $\mathrm{BaFe}_{12} \mathrm{O}_{19}$ samples. a summary of the saturation magnetization $\left(M_{\mathrm{s}}\right)$ values for the different bulk
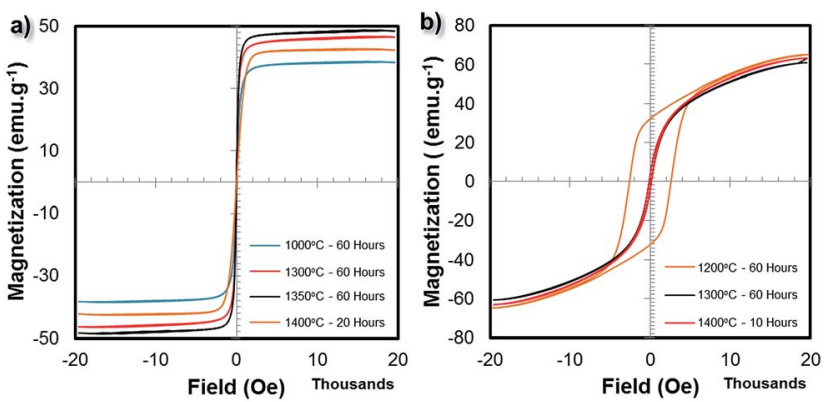

Fig. 7 Magnetic hysteresis loops of the 3D printed bulk ferrite structure samples sintered under different conditions: (a) $\mathrm{NiFe}_{2} \mathrm{O}_{4}\left(1000^{\circ} \mathrm{C} /\right.$ $60 \mathrm{~h}, 1300^{\circ} \mathrm{C} / 60 \mathrm{~h}, 1350^{\circ} \mathrm{C} / 60 \mathrm{~h}$ and $1400^{\circ} \mathrm{C} / 20 \mathrm{~h}$ ) and (b) $\mathrm{BaFe}_{12} \mathrm{O}_{19}$ $\left(1200{ }^{\circ} \mathrm{C} / 60 \mathrm{~h}, 1300^{\circ} \mathrm{C} / 60 \mathrm{~h}\right.$ and $\left.1400^{\circ} \mathrm{C} / 10 \mathrm{~h}\right)$.

ferrite samples is given in Table S2. $\dagger$ From Fig. 7a, the $M_{\mathrm{s}}$ value of the $\mathrm{NiFe}_{2} \mathrm{O}_{4}$ sample increased with sintering temperature, which was approximately $38.32 \mathrm{emu} \mathrm{g}^{-1}$ for the sample sintered at $1000{ }^{\circ} \mathrm{C} / 60 \mathrm{~h}$ and reached $48.39 \mathrm{emu} \mathrm{g}^{-1}$ for the sample sintered at $1350{ }^{\circ} \mathrm{C} / 60 \mathrm{~h}$. The increase in the $M_{\mathrm{s}}$ value for the $\mathrm{NiFe}_{2} \mathrm{O}_{4}$ samples with sintering temperature up to $1350^{\circ} \mathrm{C} / 60 \mathrm{~h}$ can be ascribed to the increase in the grain size of the $\mathrm{NiFe}_{2} \mathrm{O}_{4}$ samples, which may also indicate that the crystallinity of the $\mathrm{NiFe}_{2} \mathrm{O}_{4}$ samples slightly improved with the sintering temperature. The $M_{\mathrm{s}}$ value of the bulk $\mathrm{NiFe}_{2} \mathrm{O}_{4}$ sintered at $1350{ }^{\circ} \mathrm{C} / 60$ hours was around $\sim 86 \%$ of the bulk magnetization value $\left(56.0 \mathrm{emu} \mathrm{g}^{-1}\right)$ of the $\mathrm{NiFe}_{2} \mathrm{O}_{4}$ sample. Beyond this, at $1400{ }^{\circ} \mathrm{C} /$ $10 \mathrm{~h}$, the $M_{\mathrm{s}}$ value decreased to $42.24 \mathrm{emu} \mathrm{g}^{-1}$. This decrease can be ascribed to the increase in oxygen defects, which was observed from the previously reported XPS analysis of an $\mathrm{NiFe}_{2} \mathrm{O}_{4}$ sample sintered at a similar temperature. ${ }^{45}$ The $\mathrm{NiFe}_{2} \mathrm{O}_{4}$ samples exhibit soft magnetic material behaviour with hysteresis loops at a low coercivity field $(<100$ Oe) and high degree of saturation magnetization.

From Fig. $7 \mathrm{~b}$, the $M_{\mathrm{s}}$ value of the $\mathrm{BaFe}_{12} \mathrm{O}_{19}$ samples reached $64.94 \mathrm{emu} \mathrm{g}^{-1}$ for the sample sintered at $1200^{\circ} \mathrm{C} / 60 \mathrm{~h}$. For the samples sintered at $1300{ }^{\circ} \mathrm{C} / 60 \mathrm{~h}$ and $1400{ }^{\circ} \mathrm{C} / 10 \mathrm{~h}$, the $M_{\mathrm{s}}$ value decreased to 60.63 and $63.03 \mathrm{emu} \mathrm{g}^{-1}$, respectively. For the sample sintered at $1200{ }^{\circ} \mathrm{C} / 60 \mathrm{~h}$, a broad hysteresis loop with high coercivity and large saturation magnetization was observed, which is typical behaviour of hard magnetic materials. However, when the sintering temperature increased to $1300{ }^{\circ} \mathrm{C} / 60 \mathrm{~h}$ and $1400^{\circ} \mathrm{C} / 10 \mathrm{~h}$, much narrower hysteresis loops similar to that of soft magnetic materials were obtained. The overall grain size plays an important role in determining the hysteresis loop behaviour of $\mathrm{BaFe}_{12} \mathrm{O}_{19}$ samples. The drastic decrease in coercivity, $H_{\mathrm{C}}$, can be attributed to the large grain size of the $\mathrm{BaFe}_{12} \mathrm{O}_{19}$ structures after sintering at temperatures above $1200{ }^{\circ} \mathrm{C}$. The coercivity of ferrites usually decreases with an increase in overall grain size due to the pinning of the domains by grain boundaries. A larger grain size means a smaller grain boundary area, therefore less pinning will occur. The $M_{\mathrm{s}}$ value of the bulk $\mathrm{BaFe}_{12} \mathrm{O}_{19}$ sintered at $1200^{\circ} \mathrm{C} / 60 \mathrm{~h}$ was around $\sim 95 \%$ of the bulk magnetization value $\left(67.7 \mathrm{emu} \mathrm{g}^{-1}\right)$ of the $\mathrm{BaFe}_{12} \mathrm{O}_{19}$ sample. 
Besides VSM, the magnetic properties of the bulk ferrite samples were also studied using a superconducting quantum interference device (SQUID). Fig. $8 \mathrm{a}$ and b show the temperature dependent magnetization hysteresis loops of the $\mathrm{NiFe}_{2} \mathrm{O}_{4}(1350$ $\left.{ }^{\circ} \mathrm{C} / 60 \mathrm{~h}\right)$ and $\mathrm{BaFe}_{12} \mathrm{O}_{19}\left(1200{ }^{\circ} \mathrm{C} / 60 \mathrm{~h}\right)$ samples between $10 \mathrm{~K}$ and $300 \mathrm{~K}$. At $10 \mathrm{~K}, 100 \mathrm{~K}, 200 \mathrm{~K}$ and $300 \mathrm{~K}$, the $M_{\mathrm{s}}$ values of the $\mathrm{NiFe}_{2} \mathrm{O}_{4}\left(1350{ }^{\circ} \mathrm{C} / 60 \mathrm{~h}\right)$ sample were 54.60, 54.62, 53.88 and 50.74 emu $^{-1}$, respectively. A decrease in temperature resulted in an increase in the $M_{\mathrm{s}}$ value. The coercivity, however, did not change significantly with the decrease in temperature. Overall, the soft magnetic material behaviour with narrow hysteresis loops was retained. Similarly for the $\mathrm{BaFe}_{12} \mathrm{O}_{19}\left(1200{ }^{\circ} \mathrm{C} / 60 \mathrm{~h}\right)$ sample, at $10 \mathrm{~K}, 100 \mathrm{~K}, 200 \mathrm{~K}$ and $300 \mathrm{~K}$, the $M_{\mathrm{S}}$ values were 100.20, 100.03, 89.37 and $73.78 \mathrm{emu}^{-1}$, respectively. The coercivity values were approximately 750 Oe, 790 Oe, 1200 Oe and $2000 \mathrm{Oe}$ at $10 \mathrm{~K}, 100 \mathrm{~K}, 200 \mathrm{~K}$ and $300 \mathrm{~K}$, respectively.

Fig. 8c and $\mathrm{d}$ show the zero-field cooling (ZFC) and field cooling (FC) curves of the bulk $\mathrm{NiFe}_{2} \mathrm{O}_{4}$ and $\mathrm{BaFe}_{12} \mathrm{O}_{19}$ samples. For the ZFC experiment, the samples were first cooled down to $10 \mathrm{~K}$ from room temperature without the presence of a magnetic field. Subsequently, the net magnetization was measured under a magnetic field of 500 Oe as the temperature increased from 10 $\mathrm{K}$ to $300 \mathrm{~K}$. For the FC measurement, the samples were cooled in the presence of a magnetic field of 500 Oe while the net sample magnetization was recorded as a function of temperature. As the temperature increased from $10 \mathrm{~K}$ to $300 \mathrm{~K}$, the ZFC magnetization increased and then decreased after reaching the maximum (blocking temperature, $T_{\mathrm{B}}$ ) at around $129.17 \mathrm{~K}$ and 99.23 $\mathrm{K}$ for the $\mathrm{NiFe}_{2} \mathrm{O}_{4}\left(1350{ }^{\circ} \mathrm{C} / 60 \mathrm{~h}\right)$ and $\mathrm{BaFe}_{12} \mathrm{O}_{19}\left(1200{ }^{\circ} \mathrm{C} /\right.$ $60 \mathrm{~h})$ samples, respectively. The temperature at which the ZFC and FC curves started to separate $\left(T_{\text {Sep }}\right)$, which corresponds to the blocking of the largest particles, is above $300 \mathrm{~K}$ for both the
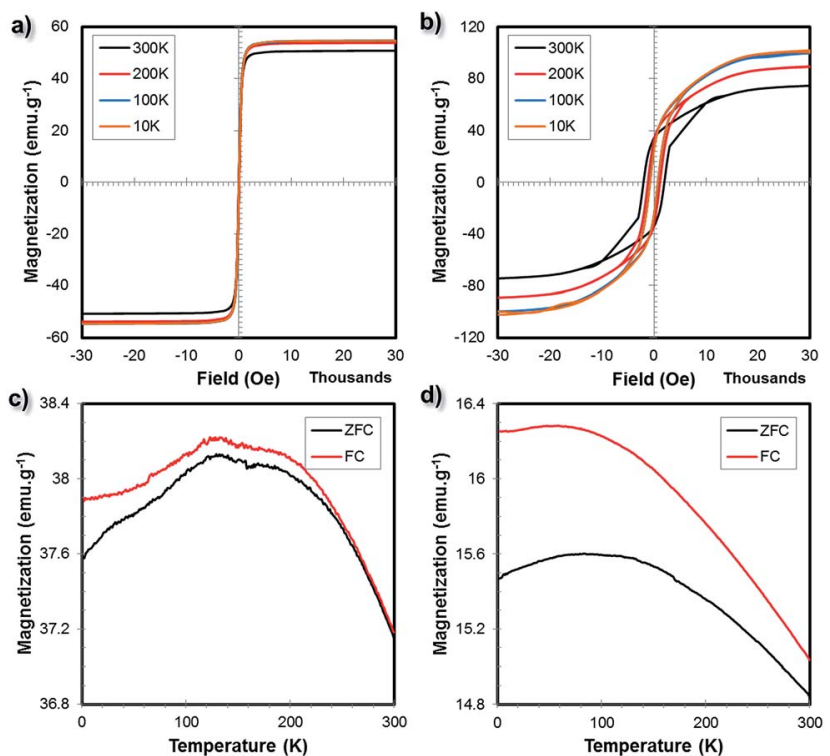

Fig. 8 Temperature dependent magnetization hysteresis loops for (a) bulk $\mathrm{NiFe}_{2} \mathrm{O}_{4}\left(1350{ }^{\circ} \mathrm{C} / 60\right.$ h) and (b) $\mathrm{BaFe}_{12} \mathrm{O}_{19}\left(1200{ }^{\circ} \mathrm{C} / 60\right.$ h) measured at the temperatures of $10 \mathrm{~K}, 100 \mathrm{~K}, 200 \mathrm{~K}$ and $300 \mathrm{~K}$ and their (c and d) ZFC and FC (500 Oe) curves, respectively.
$\mathrm{NiFe}_{2} \mathrm{O}_{4}\left(1350{ }^{\circ} \mathrm{C} / 60 \mathrm{~h}\right)$ and $\mathrm{BaFe}_{12} \mathrm{O}_{19}\left(1200{ }^{\circ} \mathrm{C} / 60 \mathrm{~h}\right)$ samples. For the bulk $3 \mathrm{D}$ printed samples, the $T_{\mathrm{B}}$ (maxima of the ZFC curves) is expected to be very different from the $T_{\text {Sep }}$ (where the ZFC and FC curves coincide) since the SEM microstructure analysis suggests large grain sizes and broad size distributions as well as dense microstructures.

\section{Porosity and density measurement}

In the previous section, it was mentioned that green bodies of $\mathrm{NiO} \cdot \mathrm{Fe}_{2} \mathrm{O}_{3}$ and $\mathrm{BaCO}_{3} \cdot \mathrm{Fe}_{2} \mathrm{O}_{3}$ with a standard cubic shape (dimension of $10 \mathrm{~mm}$ ) were fabricated. Prior to the sintering process, the as-printed green body structures were expected to possess a density of less than $50 \%$ of the theoretical density due to the presence of various organic additives (binder, plasticizer and dispersant) and water. To evaluate the density of the sintered structures, Archimedes' method was used. The relative theoretical density was calculated against the bulk theoretical density of the $\mathrm{NiFe}_{2} \mathrm{O}_{4}\left(5.38 \mathrm{~g} \mathrm{~cm}^{-3}\right)$ and $\mathrm{BaFe}_{12} \mathrm{O}_{19}(5.40 \mathrm{~g}$ $\mathrm{cm}^{-3}$ ) materials. The density of the fabricated bulk ferrite structures (with a cubic shape) obtained at different sintering temperatures were measured and plotted in Fig. 9a (for
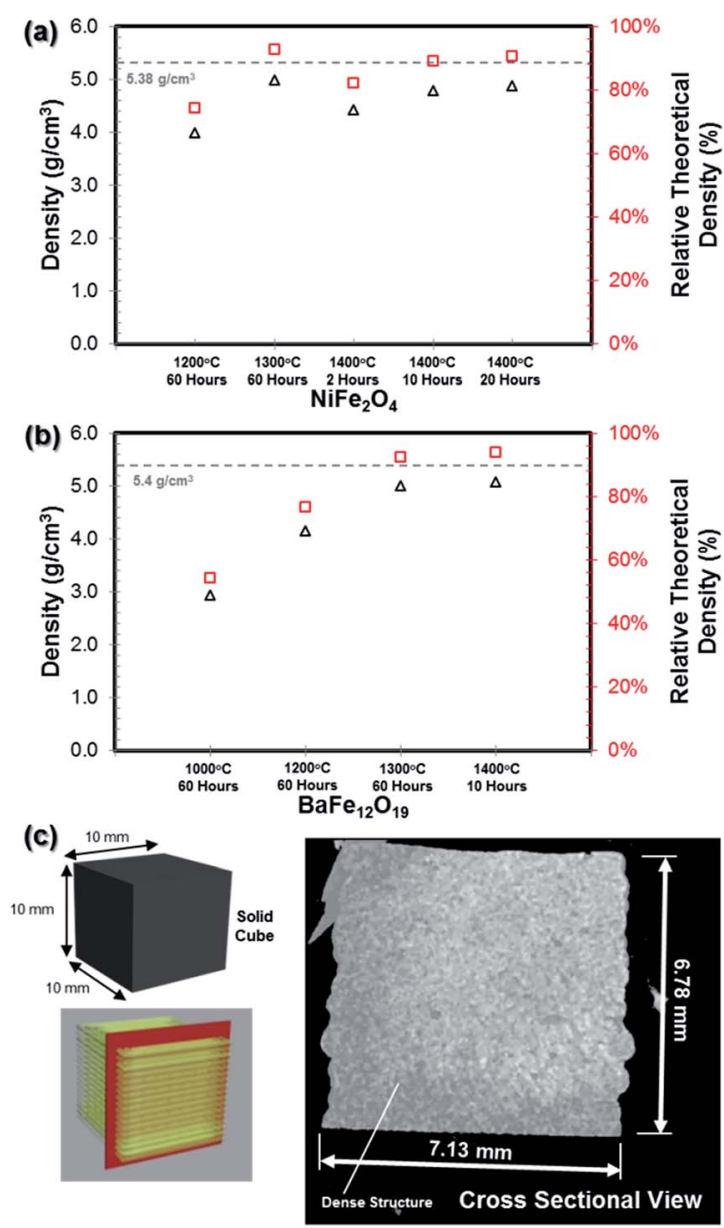

Fig. 9 Plots of the cube densities and relative theoretical densities against the sintering conditions for the bulk (a) $\mathrm{NiFe}_{2} \mathrm{O}_{4}$ and (b) $\mathrm{BaFe}_{12} \mathrm{O}_{19}$ samples. (c) Neutron CT imaging of the bulk $\mathrm{BaFe}_{12} \mathrm{O}_{19}$ sample $\left(1300{ }^{\circ} \mathrm{C} / 60 \mathrm{~h}\right)$ showing the cross section of the cube sample. 
$\mathrm{NiFe}_{2} \mathrm{O}_{4}$ ) and Fig. 9b (for $\mathrm{BaFe}_{12} \mathrm{O}_{19}$ ). From these comparisons, the green bodies comprised of the $\mathrm{NiO} \cdot \mathrm{Fe}_{2} \mathrm{O}_{3}$ and $\mathrm{BaCO}_{3} \cdot \mathrm{Fe}_{2} \mathrm{O}_{3}$ precursors were sintered completely into single phase structures with densities as high as $93 \%$ of the theoretical density values at temperatures higher than $1300{ }^{\circ} \mathrm{C}$ despite the pressure-less sintering conditions. Although the XRD analysis showed that a sintering temperature as low as $1000{ }^{\circ} \mathrm{C}$ was sufficient to obtain the desired $\mathrm{NiFe}_{2} \mathrm{O}_{4}$ and $\mathrm{BaFe}_{12} \mathrm{O}_{19}$ crystalline phases, the microstructure study (Fig. 3 and 4 ) indicates that the surfaces of the structures sintered at $1000{ }^{\circ} \mathrm{C}$ to $1200{ }^{\circ} \mathrm{C}$ were highly porous and dense microstructures were obtained only at temperatures above $1200{ }^{\circ} \mathrm{C}$.

The results presented in Fig. 9a and b suggest that the increase in sintering temperature generally resulted in a significant increase in sample density. In addition, from Fig. 9a, simply increasing the sintering duration from 2 to 10 and 20 hours at $1400{ }^{\circ} \mathrm{C}$ resulted in a slight increase in sample density for the $\mathrm{NiFe}_{2} \mathrm{O}_{4}$ sample. The increase in density with the increase in sintering temperature or duration can be correlated with the microstructural changes in the sample. This trend was accompanied by great volume shrinkage for the sintered structure. A summary of the sintered cubic structure dimensions is given in Fig. S6. $\uparrow$ The shrinkage was due to the evaporation of the solvent, burnout of organic additives and pore elimination during the densification process. These processes consequently decreased the sample net volume and enhanced the crystallization process.

It should be noted that when the grain size grew due to densification at higher temperature (Fig. $3 \mathrm{~g}$ and $4 \mathrm{e}$ ), the $M_{\mathrm{s}}$ values of the bulk ferrite structures were slightly reduced (Fig. 7). Based on the XRD patterns, magnetic properties measurement and density measurement, the optimum sintering conditions are temperature between $1200{ }^{\circ} \mathrm{C}$ to $1300{ }^{\circ} \mathrm{C}$ for a period of 60 hours for both the $\mathrm{NiFe}_{2} \mathrm{O}_{4}$ and $\mathrm{BaFe}_{12} \mathrm{O}_{19}$ samples.

In order to visualize the dense 3D-printed ferrite structure, non-destructive neutron computed tomography (CT) image analysis was performed on one of the sintered bulk $\mathrm{BaFe}_{12} \mathrm{O}_{19}$ $\left(1300{ }^{\circ} \mathrm{C} / 60 \mathrm{~h}\right.$ ) sample. ${ }^{46}$ The longitudinal scan (Fig. 9c) reveals a totally dense cross section structure without the presence of any macro cracks or pores within the internal structure of the cube. It is also clearly seen that the adjacent deposited ceramic paste extrudate (or filament) was fused cleanly to form a solid dense structure with no visible gap or pores at $16 \mu \mathrm{m}$ instrument resolution.

\section{Other shapes by extrusion free-forming process}

To demonstrate the possibility of fabricating 3D structures beyond a simple cubic shape (as demonstrated in Fig. 3 and 4), we attempted to print several other geometries using the existing printer settings and the as-prepared homogeneous metal oxide paste. A few of these structures are presented in Fig. 10. Complicated green body structures such as helical gear structures $\left(\mathrm{Fe}_{2} \mathrm{O}_{3}\right)$, rectangular and cylindrical mesh structures $\left(\mathrm{NiFe}_{2} \mathrm{O}_{4}\right)$, ring structures $\left(\mathrm{NiFe}_{2} \mathrm{O}_{4}\right.$ and $\left.\mathrm{BaFe}_{12} \mathrm{O}_{19}\right)$ as well as simple and complex cylinder structures $\left(\mathrm{BaFe}_{12} \mathrm{O}_{19}\right)$ were
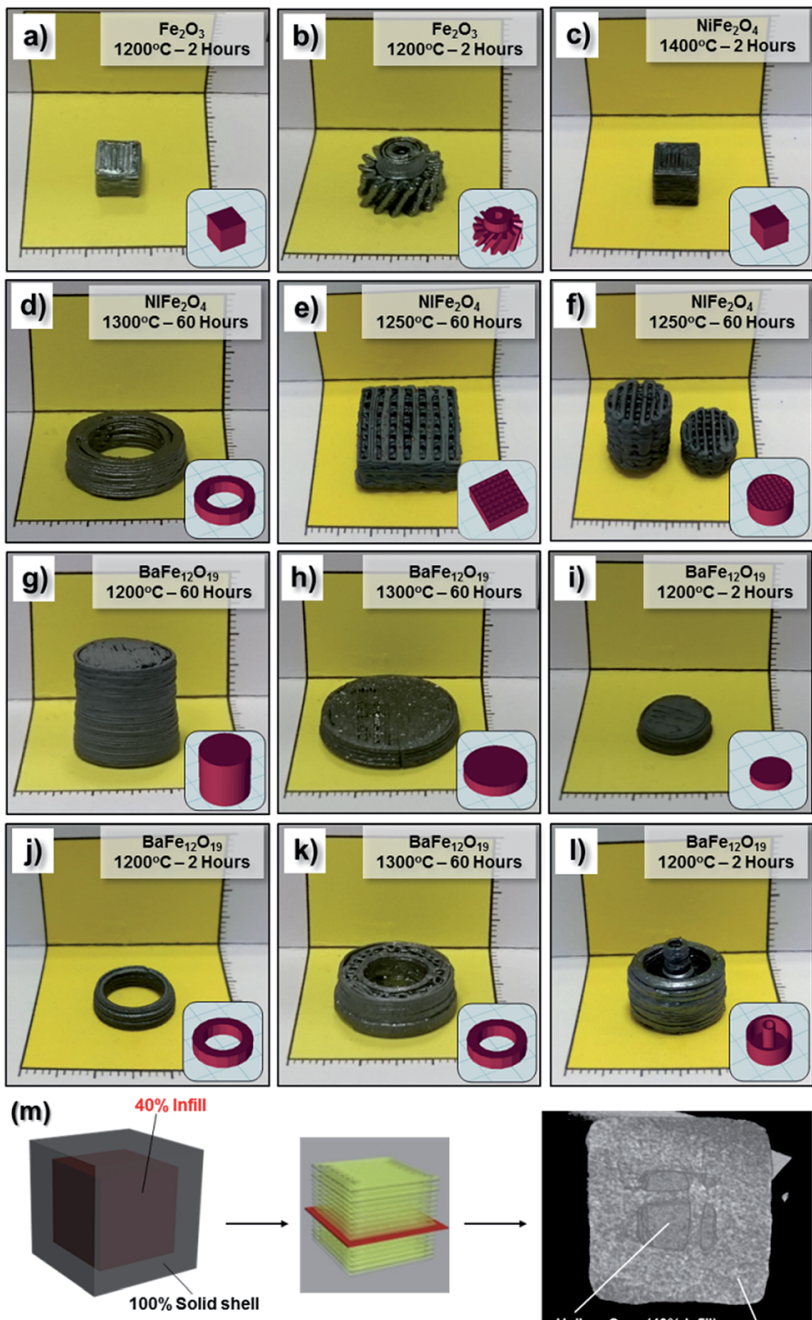

CAD Model : Cube with $40 \%$ Infill

Volume $: 661.9 \mathrm{~mm}^{3}(33.81 \%$ Porous $)$

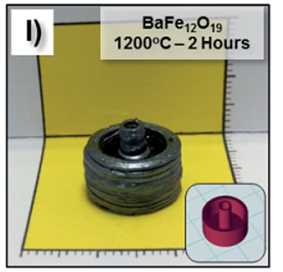

Fig. 10 Digital photographs bulk samples printed using the extrusion free-forming technique after sintering: (a) $\mathrm{Fe}_{2} \mathrm{O}_{3}$ cube, (b) $\mathrm{Fe}_{2} \mathrm{O}_{3}$ gear, (c) $\mathrm{NiFe}_{2} \mathrm{O}_{4}$ hollow cube (40\% infill), (d) $\mathrm{NiFe}_{2} \mathrm{O}_{4}$ thick ring, (e) $\mathrm{NiFe}_{2} \mathrm{O}_{4}$ hollow rectangular mesh, (f) $\mathrm{NiFe}_{2} \mathrm{O}_{4}$ cylindrical mesh, (g) $\mathrm{BaFe}_{12} \mathrm{O}_{19}$ cylinder, (h and i) $\mathrm{BaFe}_{12} \mathrm{O}_{19}$ big and small coins, ( $\mathrm{j}$ and $\mathrm{k}$ ) $\mathrm{BaFe}_{12} \mathrm{O}_{19}$ thin and thick rings, respectively, and (l) $\mathrm{BaFe}_{12} \mathrm{O}_{19}$ hollow cylinder. The sintering conditions are indicated in each respective image. Inset: respective $3 D$ renderings of the CAD models used for printing. $(\mathrm{m})$ Illustrations of the cube with an internal cavity and the corresponding neutron CT image of the sintered sample showing the cross section of the internal structure.

successfully printed and subsequently sintered into high density structures. Besides dense solid samples, samples with internal structures such as hollow cavities can also be fabricated via the EFF method. Fig. 10m shows a photograph of an internally hollow cube with $40 \%$ infill and $100 \%$ solid shell structure and the corresponding neutron CT imaging analysis of the sintered sample. From the cross sectional scan, the expected hollow core structure due to the $40 \%$ infill setting was still present even after the high temperature sintering process. This hollow core was surrounded by an outer dense shell structure. Within the centre core region, overlapping struts due to the 
layer by layer deposition process can also be seen clearly. Overall, this result suggests that complex structures with internal hollow features can be conveniently printed using the EFF technique.

Despite the advantages of the EFF technique, drying cracks on the sample surface especially on the sections closer to the printing substrate were frequently observed especially when the drying rate was too fast (e.g. oven drying). However, if the drying process is appropriately controlled, dense green body structures with negligible printing defects (e.g. sample deformation or drying cracks) can be obtained. This strategy was successfully applied during the printing of intricate structures such as an $\mathrm{Fe}_{2} \mathrm{O}_{3}$ gear (Fig. 10b) or $\mathrm{NiFe}_{2} \mathrm{O}_{4}$ rectangular mesh (Fig. 10e). In general, the EFF technique demonstrated in this work can be readily extended to other ferrites (cobalt ferrite, $\mathrm{CoFe}_{2} \mathrm{O}_{4}$, zinc ferrite, $\mathrm{ZnFe}_{2} \mathrm{O}_{4}$ and nickel zinc ferrite, $\mathrm{Ni}_{0.5} \mathrm{Zn}_{0.5} \mathrm{Fe}_{2} \mathrm{O}_{4}$ ) or titanates (barium titanate, $\mathrm{BaTiO}_{3}$ and lead zirconate titanate, $\mathrm{PbZrTiO}_{3}$ ) functional ceramic materials simply by changing the metal oxide powder precursors.

\section{Conclusions}

In conclusion, a ferrite-based soft magnet $\left(\mathrm{NiFe}_{2} \mathrm{O}_{4}\right)$ and hard magnet $\left(\mathrm{BaFe}_{12} \mathrm{O}_{19}\right)$ with unique 3D structures have been successfully fabricated from cheap mixed metal oxide powder precursors through a simple extrusion free-forming technique coupled with a high temperature solid-state reaction process. The microstructures of both 3D printed soft and hard magnets obtained at different sintering temperatures were studied by SEM. Dense microstructures with negligible pores were observed for the samples sintered above $1200{ }^{\circ} \mathrm{C}$. Highly crystalline $\mathrm{NiFe}_{2} \mathrm{O}_{4}$ and $\mathrm{BaFe}_{12} \mathrm{O}_{19}$ phases were confirmed from XRD measurements. From the VSM measurement, the printed structures possess excellent magnetic properties with saturation magnetization as high as $48.39 \mathrm{emu} \mathrm{g}^{-1}$ and $64.94 \mathrm{emu} \mathrm{g}^{-1}$ for the $\mathrm{NiFe}_{2} \mathrm{O}_{4}$ and $\mathrm{BaFe}_{12} \mathrm{O}_{19}$ samples, respectively, at room temperature. The densities of both sintered soft and hard magnet specimens are about $93 \%$ of the theoretical density values. The extrusion free-forming technique demonstrated in this work can be readily extended to other types of functional ceramic materials by simply changing the initial metal oxide powder mixture.

\section{Experimental procedures}

\section{Materials}

High purity powders of iron(III) oxide $\left(\mathrm{Fe}_{2} \mathrm{O}_{3} ;<5 \mu \mathrm{m}\right)$, barium carbonate $\left(\mathrm{BaCO}_{3}\right)$, nickel oxide (NiO; 25 mesh) as well as polyvinyl alcohol (PVA; $M_{\mathrm{w}} 31000$; Mowiol ${ }^{\circledR}$ 4-88) binder and poly(ethylene glycol) (PEG-400; $M_{\mathrm{n}}$ 400) plasticizer were purchased from Sigma Aldrich, Singapore. Solsperse 20000 hyper-dispersant was provided by Lubrizol. Throughout the experiments, deionized water (DI water) was used as the solvent. Prior to the paste preparation, a solution containing $12.5 \mathrm{wt} \%$ of polyvinyl alcohol in DI water was prepared beforehand.

\section{Preparation of mixed metal-oxide powder precursors}

Mixed metal-oxide powder precursors were prepared by grinding a stoichiometric mixture of (i) $\mathrm{Fe}_{2} \mathrm{O}_{3}$ and $\mathrm{NiO}$ (for nickel ferrite) and (ii) $\mathrm{Fe}_{2} \mathrm{O}_{3}$ and $\mathrm{BaCO}_{3}$ (for barium ferrite) using a Tefal Fruit Sensation blender (160 mL plastic mills). In most cases, $28.06 \mathrm{~g}$ of $\mathrm{NiO}$ and $12.36 \mathrm{~g}$ of $\mathrm{BaCO}_{3}$ were each homogenized with $60.0 \mathrm{~g}$ of $\mathrm{Fe}_{2} \mathrm{O}_{3}$ for approximately 3 to $4 \mathrm{~h}$.

\section{Preparation of aqueous ceramic paste}

Printable ceramic suspensions containing the mixed metaloxide powder precursors were prepared following the formulations given in Table 1 . Briefly, the powder precursors $(6.5 \mathrm{~g}$ of $\mathrm{NiO} \cdot \mathrm{Fe}_{2} \mathrm{O}_{3}$ mixture or $6.0 \mathrm{~g}$ of $\mathrm{BaCO}_{3} \cdot \mathrm{Fe}_{2} \mathrm{O}_{3}$ mixture) were added to solutions containing the PVA binder (270-280 $\mathrm{mg}$ ), PEG-400 plasticizer (220 mg) and Solsperse dispersant (30-70 $\mathrm{mg}$ ) in DI water and subsequently homogenized using an agate mortar and pestle for 5 to $10 \mathrm{~min}$. The obtained homogeneous powder-filled paste precursors for printing with approximately $34.5 \mathrm{vol} \%$ and $33.9 \mathrm{vol} \%$ for $\mathrm{NiO} \cdot \mathrm{Fe}_{2} \mathrm{O}_{3}$ and $\mathrm{BaCO}_{3} \cdot \mathrm{Fe}_{2} \mathrm{O}_{3}$, respectively, were transferred into a $10 \mathrm{~mL}$ disposable plastic syringe equipped with a plastic nozzle (diameter: $410 \mu \mathrm{m}$ ). Tips: The resultant uniform paste has to be transferred immediately into the syringe in order to avoid unnecessary water evaporation which may significantly affect the rheology of the paste afterwards. Also gentle tapping of the syringe may eliminate trapped air-bubbles.

\section{D printing}

The obtained homogeneous aqueous paste was extruded using a commercially available inexpensive FDM printer, 3Dison Multi (3Dison, South Korea), equipped with a universal extruder system (ROKIT Inc.). The STL files were prepared using Autodesk 3Dsmax. The CreatorK software was used to slice/prepare the STL file for printing (infill setting: $40 \%$ and $100 \%$; layer height: $0.6 \mathrm{~mm}$; width over height ratio: 1.45 and printing speed: $5 \mathrm{~mm} \mathrm{~s}^{-1}$ ). All samples were printed at room temperature in air. The as-printed green body structure was allowed to dry slowly at ambient temperature for 12 hours to prevent any unnecessary cracks and deformation.

\section{Post printing sintering treatment}

For the post-printing densification treatment, the dried green body was then heated in a high temperature furnace (Carbolite HTF $17 / 5$ box furnaces; UK). The debinding process was achieved by heating the green-body for $1-2 \mathrm{~h}$ at $500-600{ }^{\circ} \mathrm{C}$ in air atmosphere. Following the debinding process, the samples were heated at different temperatures $\left(1000{ }^{\circ} \mathrm{C}\right.$ to $\left.1400{ }^{\circ} \mathrm{C}\right)$ for 10,20 or $60 \mathrm{~h}$ at a constant heating rate of $1{ }^{\circ} \mathrm{C} \min ^{-1}$ in air atmosphere. After sintering, the samples were allowed to naturally cool to room temperature.

\section{Materials characterization}

Paste rheological measurements were carried out on a DHR-2 rheometer (TA Instruments) using $40 \mathrm{~mm}$ diameter parallel plates with an approximately $800 \mu \mathrm{m}$ measurement gap. The 
apparent viscosity of the paste was measured at $25{ }^{\circ} \mathrm{C}$ in the shear rate sweep mode with shear rate ranging from 0.01-40 $\mathrm{s}^{-1}$. The inorganic content in the resultant $\mathrm{BaCO}_{3} \cdot \mathrm{Fe}_{2} \mathrm{O}_{3}$ paste was analysed on an SDT Q600 thermogravimetric analyser (TA Instruments). The paste was heated up to $700{ }^{\circ} \mathrm{C}$ in an air environment and the weight loss was recorded. Transmission electron microscopy (TEM) images of the metal oxide precursors were recorded using a JEOL-3010F TEM (300 kV). The TEM sample was prepared by dripping one drop of the sample solution (in ethanol) onto the TEM copper grid, followed by a simple air-drying process in ambient conditions. The microstructures of the sintered bulk ferrites structures were observed under a scanning electron microscope (SEM) with a $5 \mathrm{kV}$ acceleration voltage (Zeiss; FESEM Supra 40). Elemental analysis was performed using energy dispersive X-ray spectroscopy (EDX) attached to the SEM. The as-sintered ferrite structures SEM images were taken directly without any grinding/polishing.

The sintered ferrite samples and precursor powders crystal structures and phase identification were examined using an Xray powder diffractometer (XRD; Bruker D8 Advanced Diffractometer system) with a $\mathrm{Cu} \mathrm{K} \alpha$ source $(1.5418 \AA$ A). The sintered ferrite structures were examined directly without any grinding into fine powder during the XRD experiment. The X-ray photoelectron spectroscopy (XPS) spectra of the as-sintered ferrite structures were obtained using an Axis Ultra DLD X-ray photoelectron spectrophotometer equipped with an $\mathrm{Al} \mathrm{K} \alpha \mathrm{X}$-ray source $(1486.69 \mathrm{eV})$. The energy step size of the XPS was $1 \mathrm{eV}$ for the survey scans and $0.1 \mathrm{eV}$ for the fine scans. Subtraction of the Shirley background composition analysis and XPS peak deconvolution were carried out using Casa XPS (2.3.14 version). XPS spectra were calibrated to the $\mathrm{sp}^{2}$ hybridized carbon peak at $284.6 \mathrm{eV}$. The magnetic properties of the as-sintered ferrite samples were studied using both (i) a Lakeshore 5407 vibrating sample magnetometer (VSM) at room temperature (with an external magnetic field between $-20 \mathrm{kOe}$ to $20 \mathrm{kOe}$ ) and (ii) a superconducting quantum interference device (SQUID) without any post-processing treatment (e.g. grinding or polishing). Zero field cooling (ZFC) and field cooling (FC) curves with an applied external magnetic field of 500 Oe were recorded. Magnetization hysteresis loops were measured at $10 \mathrm{~K}, 100 \mathrm{~K}$, $200 \mathrm{~K}$ and $300 \mathrm{~K}$ (with an external magnetic field between -30 kOe to $30 \mathrm{kOe}$ ). The density, $\rho$, of the sintered ferrite structures was determined via the Archimedes method using a Matsumoku electronic densimeter. The neutron imaging measurement protocols can be found in ESI Section S7.†

\section{Acknowledgements}

This project is financially supported by NUS Strategic Research Fund R-261-509-001-646 and R-261-509-001-733 and NRF NRFCRP16-2015-01 (R284-000-159-281).

\section{References}

1 R. E. Newnham, Rep. Prog. Phys., 1989, 52, 123.

2 J.-S. Park, H. Kim and I.-D. Kim, J. Electroceram., 2014, 32, 117-140.
3 J. F. Tressler, S. Alkoy and R. E. Newnham, J. Electroceram., 1998, 2, 257-272.

4 B. W. Pavel, Phys.-Usp., 1987, 30, 729.

5 I. G. Aleksander, Phys.-Usp., 1987, 30, 659.

6 M. Sugimoto, J. Am. Ceram. Soc., 1999, 82, 269-280.

7 R. C. Pullar, Prog. Mater. Sci., 2012, 57, 1191-1334.

8 M. Goel, Ceram. Int., 2004, 30, 1147-1154.

9 V. Esposito and E. Traversa, J. Am. Ceram. Soc., 2008, 91, 1037-1051.

10 N. Izyumskaya, Y. I. Alivov, S. J. Cho, H. Morkoç, H. Lee and Y. S. Kang, Crit. Rev. Solid State Mater. Sci., 2007, 32, 111-202.

11 A. C. F. M. Costa, E. Tortella, M. R. Morelli and R. H. G. A. Kiminami, J. Magn. Magn. Mater., 2003, 256, 174-182.

12 A. S. Bhalla, R. Guo and R. Roy, Mater. Res. Innovations, 2000, 4, 3-26.

13 M. Pardavi-Horvath, J. Magn. Magn. Mater., 2000, 215-216, 171-183.

14 V. G. Harris, A. Geiler, Y. Chen, S. D. Yoon, M. Wu, A. Yang, Z. Chen, P. He, P. V. Parimi, X. Zuo, C. E. Patton, M. Abe, O. Acher and C. Vittoria, J. Magn. Magn. Mater., 2009, 321, 2035-2047.

15 E. Schloemann, J. Magn. Magn. Mater., 2000, 209, 15-20.

16 G. Jian, D. Zhou, J. Yang and Q. Fu, J. Magn. Magn. Mater., 2012, 324, 4179-4183.

17 T. Y. Tseng and J. C. Lin, IEEE Trans. Magn., 1989, 25, 44054408.

18 L. Lv, J.-P. Zhou, Q. Liu, G. Zhu, X.-Z. Chen, X.-B. Bian and P. Liu, Phys. E, 2011, 43, 1798-1803.

19 H. Sözeri, J. Alloys Compd., 2009, 486, 809-814.

20 T. Ugur, Chin. Phys. Lett., 2010, 27, 117503.

21 N. Travitzky, A. Bonet, B. Dermeik, T. Fey, I. Filbert-Demut, L. Schlier, T. Schlordt and P. Greil, Adv. Eng. Mater., 2014, 16, 729-754.

22 A. Zocca, P. Colombo, C. M. Gomes and J. Günster, J. Am. Ceram. Soc., 2015, 98, 1983-2001.

23 J. A. Lewis, J. Am. Ceram. Soc., 2000, 83, 2341-2359.

24 J. A. Lewis, J. E. Smay, J. Stuecker and J. Cesarano, J. Am. Ceram. Soc., 2006, 89, 3599-3609.

25 J. W. Halloran, Annu. Rev. Mater. Res., 2016, 46, 19-40.

26 R. Felzmann, S. Gruber, G. Mitteramskogler, P. Tesavibul, A. R. Boccaccini, R. Liska and J. Stampfl, Adv. Eng. Mater., 2012, 14, 1052-1058.

27 B. Qian and Z. Shen, J. Asian Ceram. Soc., 2013, 1, 315-321.

28 P. Bertrand, F. Bayle, C. Combe, P. Goeuriot and I. Smurov, Appl. Surf. Sci., 2007, 254, 989-992.

29 S. M. Gaytan, M. A. Cadena, H. Karim, D. Delfin, Y. Lin, D. Espalin, E. MacDonald and R. B. Wicker, Ceram. Int., 2015, 41, 6610-6619.

30 J. A. Gonzalez, J. Mireles, Y. Lin and R. B. Wicker, Ceram. Int., 2016, 42, 10559-10564.

31 I. Grida and J. R. G. Evans, J. Eur. Ceram. Soc., 2003, 23, 629635.

32 M. Faes, H. Valkenaers, F. Vogeler, J. Vleugels and E. Ferraris, Procedia CIRP, 2015, 28, 76-81. 
33 Z. Chen, X. Song, L. Lei, X. Chen, C. Fei, C. T. Chiu, X. Qian, T. Ma, Y. Yang, K. Shung, Y. Chen and Q. Zhou, Nano Energy, 2016, 27, 78-86.

34 Y. Yang, Z. Chen, X. Song, B. Zhu, T. Hsiai, P.-I. Wu, R. Xiong, J. Shi, Y. Chen, Q. Zhou and K. K. Shung, Nano Energy, 2016, 22, 414-421.

35 I. V. Shishkovskii, M. V. Kuznetsov and Y. G. Morozov, Glass Ceram., 2003, 60, 174-178.

36 D. M. Gureev, R. V. Ruzhechko and I. V. Shishkovskii, Tech. Phys. Lett., 2000, 26, 262-264.

37 B. A. Tuttle, J. E. Smay, J. Cesarano, J. A. Voigt, T. W. Scofield, W. R. Olson and J. A. Lewis, J. Am. Ceram. Soc., 2001, 84, 872874.

38 X. Wei, R. S. Nagarajan, E. Peng, J. Xue, J. Wang and J. Ding, Ceram. Int., 2016, 42, 15836-15842.
39 S. S. Nadkarni and J. E. Smay, J. Am. Ceram. Soc., 2006, 89, 96-103.

40 A. E. Jakus, S. L. Taylor, N. R. Geisendorfer, D. C. Dunand and R. N. Shah, Adv. Funct. Mater., 2015, 25, 6985-6995.

41 J. N. Stuecker, J. Cesarano Iii and D. A. Hirschfeld, J. Mater. Process. Technol., 2003, 142, 318-325.

42 J. Powell, S. Assabumrungrat and S. Blackburn, Powder Technol., 2013, 245, 21-27.

43 D. Cerović, I. Momčilović and S. J. Kiss, J. Mater. Sci., 1969, 4, 174-178.

44 G. C. Bye and C. R. Howard, J. Appl. Chem. Biotechnol., 1971, 21, 319-323.

45 Z. Shi, J. Zhang, D. Gao, Z. Zhu, Z. Yang, Z. Zhang and D. Xue, Nanoscale Res. Lett., 2013, 8, 404.

46 U. Garbe, T. Randall and C. Hughes, Nucl. Instrum. Methods Phys. Res., Sect. A, 2011, 651, 42-46. 